Canadian Science Publishing

Applied Physiology, Nutrition, and Metabolism Physiologie appliquée, nutrition et métabolisme

\title{
Food ingestion in an upright sitting position increases post- prandial amino acid availability when compared to food ingestion in a lying down position
}

\begin{tabular}{|r|l|}
\hline Journal: & Applied Physiology, Nutrition, and Metabolism \\
\hline Manuscript ID & apnm-2016-0522.R1 \\
\hline Manuscript Type: & Article \\
\hline Date Submitted by the Author: & 02-Jan-2017 \\
\hline Complete List of Authors: & $\begin{array}{l}\text { Holwerda, Andrew; Maastricht University, Department of Human Biology } \\
\text { and Movement Sciences } \\
\text { Lenaerts, Kaatje; Maastricht University, Department of Surgery } \\
\text { Bierau, Jörgen; Maastricht University Medical Centre+, Department of } \\
\text { Clinical Genetics } \\
\text { Wodzig, Will; Maastricht University Medical Centre+, Central Diagnostic } \\
\text { Laboratory } \\
\text { van Loon, Luc; Maastricht University, Department of Human Biology and } \\
\text { Movement Sciences }\end{array}$ \\
\hline Keyword: & \begin{tabular}{l} 
Protein, digestion, gastric emptying, body position, amino acids \\
\hline
\end{tabular} \\
\hline
\end{tabular}




\section{Food ingestion in an upright sitting position increases} post-prandial amino acid availability when compared to

\section{food ingestion in a lying down position}

Andrew M. Holwerda ${ }^{1}$, Kaatje Lenaerts ${ }^{2}$, Jörgen Bierau ${ }^{3}$, Will K.W.H. Wodzig ${ }^{4}$, and Luc J.C. van Loon ${ }^{1, *}$

${ }^{1}$ Department of Human Biology and Movement Sciences, NUTRIM School of Nutrition and Translational Research in Metabolism, Maastricht University, Maastricht, the Netherlands ${ }^{2}$ Department of Surgery, NUTRIM School of Nutrition and Translational Research in Metabolism, Maastricht University, Maastricht, the Netherlands, ${ }^{3}$ Department of Clinical Genetics, Maastricht University Medical Centre+, Maastricht, the Netherlands ${ }^{4}$ Central Diagnostic Laboratory, Maastricht University Medical Centre+, the Netherlands

Last names for PubMed indexing: Holwerda, Lenaerts, Bierau, Wodzig, van Loon Corresponding author: Professor L.J.C. van Loon, PhD, NUTRIM School of Nutrition and Translational Research in Metabolism, Maastricht University Medical Center+, PO Box 616, 6200 MD Maastricht, the Netherlands, e-mail: L.vanLoon@maastrichtuniversity.nl.

Word count (abstract through references): 4,973

Number of figures (to print, not OSM): 4

Number of tables (to print, not OSM): 0

Running head: Body positioning and protein digestion

Clinical Trial Registration Number: NTR5027 (http://www.trialregister.nl /) 


\section{ABSTRACT (248 words)}

Dietary protein digestion and absorption kinetics determine the post-prandial increase in muscle protein synthesis. We recently demonstrated that body position during feeding can modulate the post-prandial rise in plasma amino acid availability. Here we investigated whether protein ingestion in an upright sitting body position accelerates gastric emptying and improves dietary protein digestion and subsequent amino acid absorption compared with feeding in a supine lying body position. In a crossover design, eight young males $(26 \pm 1 \mathrm{y}$, $24.0 \pm 0.9 \mathrm{kgm}^{-2}$ ) ingested $20 \mathrm{~g}$ intrinsically L-[1- $\left.{ }^{13} \mathrm{C}\right]$-phenylalanine labeled milk protein plus $1.5 \mathrm{~g}$ paracetamol while sitting in an upright position or lying down in a supine position. Blood samples were collected frequently during a $5 \mathrm{~h}$ post-prandial period. Gastric emptying rates and dietary protein digestion and absorption were assessed using plasma paracetamol and amino acid concentrations as well as plasma L- $\left[1-{ }^{13} \mathrm{C}\right]$-phenylalanine enrichments. Peak plasma leucine concentrations were higher when protein was ingested in an upright sitting vs lying position $\left(213 \pm 15\right.$ vs $\left.193 \pm 12 \mu \mathrm{mol} \mathrm{L}^{-1}, \mathrm{P}<0.05\right)$, which was accompanied by a trend for a greater overall leucine response ( $13989 \pm 720$ vs $11875 \pm 1073$ AU, respectively; $\mathrm{P}=0.05)$. Peak plasma paracetamol concentrations were higher in the sitting vs lying treatment $(11.6 \pm 0.5 \mathrm{vs}$ $\left.9.3 \pm 0.6 \mathrm{mg} \cdot \mathrm{L}^{-1}, \mathrm{P}<0.05\right)$. Protein ingestion in an upright sitting position accelerates gastric emptying and increases the post-prandial rise in plasma amino acid availability by increasing protein digestion and amino acid absorption rates. Therefore, feeding in an upright body position as opposed to a lying position is an important prerequisite to allow proper postprandial muscle protein accretion.

Trial Registration: NTR5027 (http://www.trialregister.nl/)

Key words: Protein, digestion, gastric emptying, body position, amino acids, leucine, postprandial 


\section{INTRODUCTION}

Protein ingestion increases muscle protein synthesis rates (Yang et al. 2012b, 2012a, Burd et al. 2015). The post-prandial increase in muscle protein synthesis rate has been attributed to the rise in circulating (essential) amino acid concentrations, with the post-prandial rise in circulating plasma leucine concentrations being of particular relevance (Dreyer et al. 2008, Wall et al. 2013). Regulation of the post-prandial muscle protein synthetic response occurs on multiple levels, ranging from protein digestion and amino acid absorption (Koopman et al. 2009), post-prandial insulin release and subsequent muscle perfusion (Rasmussen et al. 2006), amino acid uptake in muscle (Dickinson et al. 2013), activation of anabolic signaling pathways (Fry et al. 2011), and subsequent myofibrillar protein synthesis (Yang et al. 2012b, 2012a, Burd et al. 2015). Differences in the anabolic properties of various proteins have been attributed to their amino acid composition (Churchward-Venne et al. 2012) as well as their specific protein digestion and amino acid absorption kinetics (Calbet and Holst 2004).

The post-prandial muscle protein synthetic response to feeding is influenced by various factors that may modulate post-prandial protein digestion and amino acid absorption (Dangin et al. 2001, Koopman et al. 2009, Pennings et al. 2011). For example, the post-prandial stimulation of muscle protein synthesis can be influenced by the type of protein (Dangin et al. 2001, Pennings et al. 2011), the matrix in which the protein is consumed (Soop et al. 2012, Churchward-Venne et al. 2015), the macronutrient composition of a protein rich meal (Gorissen et al. 2014) as well as actual food preparation procedures (Bax et al. 2012, Pennings et al. 2013) and mastication (Dreyer and Volpi 2005). We recently identified body position during and/or after feeding as an important factor influencing the post-prandial muscle protein synthetic response. We demonstrated that ingesting 22 g protein in a head-down tilted body position slows down gastric emptying rate and substantially lowers post-prandial plasma 
amino acid availability when compared to the ingestion of the same amount of protein in a proper upright sitting body position (Holwerda et al. 2016).

Based upon these proof-of-principle findings, we hypothesized that food intake in an upright sitting position results in more rapid gastric emptying, thereby accelerating protein digestion and subsequent amino acid absorption when compared to feeding in a lying position. Understanding the impact of body position on protein digestion and absorption is of important clinical relevance as many patients in the hospital remain in a lying position during and/or after feeding. Based upon our hypothesis, feeding in a lying body position could impair postprandial protein handling and, as such, contribute to the development of anabolic resistance during bed rest following injury or disease.

To test our hypothesis that post-prandial protein handling differs when protein is ingested in an upright sitting versus lying down position, we selected a group of males who were subjected to two experiments where gastric emptying rate and protein digestion were assessed after consuming $20 \mathrm{~g}$ protein in an upright sitting versus lying down position. To simultaneously assess gastric emptying rates and protein digestion and amino acid absorption, subjects were administered $20 \mathrm{~g}$ intrinsically $\mathrm{L}-\left[1-{ }^{13} \mathrm{C}\right]$-phenylalanine-labeled milk protein (van Loon et al. 2009) mixed with 1.5 g paracetamol (acetaminophen) (van Can et al. 2014, Panahi et al. 2014, Holwerda et al. 2016). This study extends upon our previous work (Holwerda et al. 2016) and shows that protein ingestion in an upright, sitting body position accelerates gastric emptying rate when compared to protein ingestion in a lying down body position, resulting in more rapid protein digestion and amino acid absorption. 


\section{MATERIALS \& METHODS}

\section{Subjects}

Eight healthy young subjects $\left(26 \pm 1 \mathrm{y}, 24.0 \pm 0.9 \mathrm{~kg} \cdot \mathrm{m}^{-2}\right)$ participated in this randomized, cross-over trial. Subjects were included if they were between the ages of 18 and $35 \mathrm{y}$ with a BMI between 18 and $30 \mathrm{~kg} \cdot \mathrm{m}^{-2}$. Potential subjects were excluded if they reported gastrointestinal dysfunction/disease (lactose intolerance, celiac disease) or if they were taking any form of medication that could impair gastrointestinal function. All participants were informed about the purpose of the study, experimental procedures, and possible risks prior to providing written consent to participate. This study was approved by the Medical Ethical Committee of the Maastricht University Medical Centre, The Netherlands and conformed to standards for the use of human subjects in research as outlined in the seventh revision of the Declaration of Helsinki (Brazil, 2013). This study was registered at the Netherlands Trial Register (http://www.trialregister.nl) as NTR5027.

\section{Diet and physical activity before testing}

All subjects were instructed to keep their diet consistent, to refrain from alcohol consumption and to refrain from performing any exhaustive physical activity for two days before each test day. Subjects reported to the lab for each test day under resting and fasted conditions, having not eaten anything from $2200 \mathrm{~h}$ the night before testing.

\section{Experimental procedure}

According to the randomized, cross-over study design, each subject ingested $20 \mathrm{~g} \mathrm{~L}-\left[1-{ }^{13} \mathrm{C}\right]-$ phenylalanine-labeled milk protein (MPC80) mixed with $1.5 \mathrm{~g}$ paracetamol powder (acetaminophen, Kruidvat, Leiden, The Netherlands) once while sitting in an upright body 
position and once while lying in a supine horizontal body position. Subjects remained in the respective body position for the duration of each trial (330 min total). Each trial was separated by a minimum of 6 days. Subjects ingested the test drink through a spout of a sports drink bottle to prevent any spillage. Drink ingestion time in both treatment positions was standardized to $5 \mathrm{~min}$. The provision of paracetamol in combination with repeated blood sampling over a $5 \mathrm{~h}$ post-prandial period allowed for assessment of gastric emptying rate (see below for methodological description). The provision of intrinsically L- $\left[1-{ }^{13} \mathrm{C}\right]-$ phenylalanine-labeled protein combined with repeated blood sampling over a $5 \mathrm{~h}$ postprandial period allows assessment of dietary protein digestion and amino acid absorption. Upon ingestion and subsequent digestion of the intrinsically L- $\left[1-{ }^{13} \mathrm{C}\right]$-phenylalanine-labeled protein, increases in $\mathrm{L}-\left[1-{ }^{13} \mathrm{C}\right]$-phenylalanine enrichment in the circulation provide a reference measurement for protein digestion and subsequent absorption of dietary proteinderived amino acids.

\section{Testing Protocol}

After an overnight fast, a polyurethane catheter was placed in the antecubetal vein of the elbow for frequent blood sampling. At $\mathrm{t}=-30 \mathrm{~min}$, a basal blood sample was collected from the catheter and blood pressure and heart rate was measured once at the upper arm and once at the ankle. After baseline measurements, subjects positioned themselves in either the sitting or supine position based on randomization. While in the seated position, subjects sat in a standardized, stationary chair with arm rests and were instructed to hold their lower back against the back support of the chair. Subjects were supervised throughout the test day and were constantly reminded to maintain the upright posture. For the lying treatment, subjects were laid in a standard hospital bed and were instructed to lay supine for the duration of the trial. Subjects were given a pillow to rest their heads, which was positioned so that the upper 
back would remain in contact with the bed. After subjects were positioned in the respective body positions of each treatment, they acclimatized for $30 \mathrm{~min}$, after which another blood sample was collected and blood pressure and heart rate were measured $(t=0 \mathrm{~min})$. Following these measurements, the test drink was ingested, signifying the start of the 300 min postprandial period. Venous blood samples were collected at $\mathrm{t}=15,30,45,60,90,120,180,240$ and 300 min. Blood samples were collected in EDTA containing tubes and centrifuged at $1000 \mathrm{~g}$ for $10 \mathrm{~min}$ at $4^{\circ} \mathrm{C}$. Aliquots of plasma were frozen in liquid nitrogen and stored at $80^{\circ} \mathrm{C}$. Blood pressure and heart rate was measured at the upper arm and ankle at $\mathrm{t}=60,120$, $180,240,300 \mathrm{~min}$.

\section{Preparation of study beverage}

Subjects ingested $20 \mathrm{~g}$ intrinsically L-[1- $\left.{ }^{13} \mathrm{C}\right]$-phenylalanine-labeled milk protein (MPC80) with an added $1.5 \mathrm{~g}$ paracetamol powder dissolved in water up to $500 \mathrm{~mL}$. We chose to use intrinsically labeled milk as opposed to either rapid or more slowly digestible whey or micellar casein fractions (Dangin et al. 2001, Koopman et al. 2009), as milk and milk protein based products are generally part of our diets. The intrinsically L- $\left[1-{ }^{13} \mathrm{C}\right]$-phenylalaninelabeled milk protein was obtained by infusing a Holstein cow with large quantities of L-[1-

$\left.{ }^{13} \mathrm{C}\right]$-phenylalanine, collecting the milk and purifying the milk protein fraction as described previously (van Loon et al. 2009). The L- $\left[1-{ }^{13} \mathrm{C}\right]$-phenylalanine enrichment of the intact MPC80 was 7.7 mole percent excess (MPE). The MPC80 met all chemical and bacteriologic specifications for human consumption.

\section{Gastric Emptying}

Gastric emptying was assessed by measuring the post-prandial rise in plasma paracetamol (acetaminophen) concentrations after ingestion of protein with $1.5 \mathrm{~g}$ paracetamol added 
(Glerup et al. 2007). With paracetamol being rapidly absorbed in the small intestine, gastric emptying forms the rate-limiting step determining the appearance rate of paracetamol in the circulation. Peak plasma paracetamol concentrations are typically reached after 30-60 min following ingestion with a $\mathrm{t} 1 / 2$ of $\sim 2 \mathrm{~h}$ (van Can et al. 2014). We used plasma paracetamol appearance in the circulation as a marker of gastric emptying as applied previously in our laboratory (van Can et al. 2014, Holwerda et al. 2016) as well as others (Horowitz et al. 2012, Panahi et al. 2014).

\section{Plasma analysis}

Plasma glucose and insulin concentrations were analyzed using commercially available kits (Glucose HK CP, Horiba ABX Diagnostics, France, Ref: AA11A01667, and Human Insulinspecific (RIA), Merck Millipore, Germany, Cat \#: HI-14K, respectively). Plasma (100 $\mu \mathrm{L})$ for amino acid analyses was deproteinized on ice with 5-sulphosalicylic acid, mixed and the clear supernatant was collected after centrifugation. Amino acid profiles were determined using ultra-performance liquid chromatography tandem mass spectrometry (UPLC-MS/MS) as described previously (Waterval et al. 2009). Plasma paracetamol concentrations were analyzed with an acetaminophen assay kit (K991598, Roche, Basel, Switzerland) with the COBAS-Integra 800 immuno-assay analyzer. Briefly, acetaminophen is hydrolyzed to paminophenol and acetate. The p-aminophenol is then converted to an indophenol by enzymatic reaction. The production of indophenol is colorimetrically analyzed and is directly proportional to acetaminophen concentration in plasma.

\section{Statistical analysis}

The study was powered according to an anticipated difference in plasma leucine peak concentrations. Based on previously published data (Pennings et al. 2011, Holwerda et al. 
2016), we expected the mean effect difference in peak plasma leucine concentrations to be approximately $30 \mu \mathrm{mol} \cdot \mathrm{L}^{-1}$ and the standard deviation to be approximately $25 \mu \mathrm{mol} \mathrm{L}^{-1}$. A sample size of 8 subjects was calculated using a power of $80 \%(1-\beta=0.8)$ and a two-sided significance level of $5 \%(\alpha=0.05)$. All data are expressed as mean \pm SEM. Time-dependent variables (i.e. plasma glucose and insulin concentrations, plasma amino acid concentrations, plasma L- $\left[1-{ }^{13} \mathrm{C}\right]$-phenylalanine enrichments and plasma paracetamol concentrations) were analyzed by two-factor repeated measures ANOVA. The analysis was carried out for the period starting at the time of protein ingestion, between $t=0$ and $300 \mathrm{~min}$. Upon identification of a significant interaction, Bonferroni post hoc testing was used to identify time points in which the treatments were different. Differences in treatment-dependent variables, such as area under the curve (AUC), were analyzed using student's paired t-test. Pearson's $r$ product moment correlation was used to examine the linear relationship between plasma leucine amino acid and paracetamol AUC for each test. Statistical significance was set at $\mathrm{P}<0.05$. All calculations were performed using SPSS 21.0 (IBM, Chicago, Illinois, USA). 


\section{RESULTS}

\section{Plasma glucose and insulin}

Plasma glucose concentrations (Figure 1A) decreased slightly following protein intake in both treatments (time effect, $\mathrm{P}<0.01$ ). Plasma insulin concentrations (Figure 1B) increased following protein ingestion in both treatments (time effect, $\mathrm{P}<0.01$ ). The changes in plasma glucose and insulin concentrations were different between the sitting and lying treatments (time $\times$ treatment interaction, $\mathrm{P}<0.05$ ). Peak post-prandial insulin concentrations were reached at $\mathrm{t}=15 \mathrm{~min}$ and tended to be lower in the lying vs sitting treatment ( $20 \pm 5$ vs $25 \pm 3$ $\left.\mathrm{mU} \cdot \mathrm{L}^{-1}, \mathrm{P}=0.09\right)$

\section{Plasma amino acid responses}

Plasma leucine (Figure 2A), total essential (Figure 2B) and total non-essential (Figure 2C) amino acid concentrations increased following protein ingestion in both treatments compared with baseline $(\mathrm{P}<0.01)$. Plasma leucine and total essential amino acid concentrations showed an attenuated rise in the lying compared with the sitting treatment (time $\times$ treatment, $\mathrm{P}<0.05$ ), with concentrations being significantly lower between $\mathrm{t}=30-45$ min in the lying compared with sitting position $(\mathrm{P}<0.05)$. Overall plasma leucine availability, assessed using AUC analysis over $300 \mathrm{~min}$, tended to be lower in the lying compared with sitting treatment $(\mathrm{P}=0.05)$. No significant differences in overall plasma essential and non-essential availability over 300 min were observed after protein ingestion between treatments $(\mathrm{P}>0.05)$. After protein ingestion, plasma $\left[1-{ }^{13} \mathrm{C}\right]$-phenylalanine enrichments (Figure 3), originating from the ingested protein, increased rapidly in both treatments reaching maximal values of $2.0 \pm 0.2$ MPE at $\mathrm{t}=30 \mathrm{~min}$ in the sitting treatment and $1.9 \pm 0.1 \mathrm{MPE}$ at $\mathrm{t}=60 \mathrm{~min}$ in the supine lying treatment (main effect for time, $\mathrm{P}<0.01$, time $\times$ treatment interaction, $\mathrm{P}<0.01$ ). 


\section{Gastric emptying}

Plasma paracetamol concentrations (Figure 4) increased following protein ingestion in both treatments $(\mathrm{P}<0.05)$. Peak paracetamol concentrations reached $11.2 \pm 0.8 \mathrm{mgL}^{-1}$ at $\mathrm{t}=45 \mathrm{~min}$ in the sitting treatment and $9.3 \pm 0.6 \mathrm{mg} \mathrm{L}^{-1}$ at $\mathrm{t}=90 \mathrm{~min}(\mathrm{P}<0.05)$ in the supine lying treatment. Gastric emptying during the early post-prandial phase, assessed by paracetamol AUC between $\mathrm{t}=0-60$ min was $23 \pm 7 \%$ lower in the lying compared with sitting treatment $(521 \pm 45$ vs $395 \pm 42 \mathrm{AU}$ (arbitrary units); $\mathrm{P}<0.01$ ). When assessed over the entire $300 \mathrm{~min}$ postprandial period, paracetamol AUC no longer differed between treatments $(\mathrm{P}>0.05)$. 


\section{DISCUSSION}

In the present study, we observed that gastric emptying rate was accelerated when protein was ingested in an upright sitting versus supine lying body position. The post-prandial rise in circulating leucine concentrations was greater when protein was ingested in the upright sitting position, which was accompanied by a trend for greater overall plasma leucine availability when compared to the lying position.

The postprandial rise in plasma essential amino acids, and leucine in particular, is a key factor for driving the stimulation of postprandial muscle protein synthesis (Dreyer et al. 2008, Wall et al. 2013). In the present study, ingestion of a meal-like amount of protein rapidly increased plasma insulin (Figure 1B), essential amino acids (Figure 2B), and leucine (Figure 2A) concentrations. The post-prandial rise in plasma amino acid availability was attributed to the appearance of dietary protein-derived amino acids in the circulation, as evidenced by the post-prandial rise in both plasma phenylalanine concentration and L-[1-

${ }^{13} \mathrm{C}$ ]-phenylalanine enrichments (Figure 3). When protein was ingested in the sitting position, plasma essential amino acid concentrations reached peak levels of $1277 \pm 69 \mu \mathrm{mol} \mathrm{L}^{-1}$, with plasma leucine concentrations reaching $223 \pm 14 \mu \mathrm{mol} \cdot \mathrm{L}^{-1}$. Such post-prandial increases in plasma essential amino acid concentrations, and plasma leucine in particular, have previously been shown to increase muscle protein synthesis rates by $30-100 \%$ when compared to basal, post-absorptive muscle protein synthesis rates (Yang et al. 2012b, 2012a, Gorissen et al. 2014, Churchward-Venne et al. 2015, Burd et al. 2015).

The same, meal-like amount of protein ingested in the lying down position resulted in a blunted post-prandial rise in plasma insulin (Figure 1B), total essential amino acids (Figure 2B) and leucine (Figure 2A) concentrations when compared to protein intake in an upright sitting position. After protein ingestion in the lying down position, peak plasma leucine concentration reached $193 \pm 12 \mu \mathrm{mol}^{-1}$, which was significantly lower when compared with 
post-prandial peak plasma leucine concentrations observed following protein ingestion in a seated position. In accordance, plasma leucine availability over the entire $5 \mathrm{~h}$ post-prandial period was $15 \pm 6 \%$ less following protein ingestion in the lying versus upright, seated position $(\mathrm{P}=0.05)$. The attenuated rise in post-prandial plasma leucine availability observed between in the upright sitting and lying down positions is in line with previous proof-ofprinciple data from our lab comparing plasma amino acid availability after protein ingestion in an upright sitting versus head-tilted down body position (Holwerda et al. 2016). The blunted post-prandial rise in plasma leucine and total essential amino acid concentrations after protein ingestion in a lying down position would unlikely suffice to induce a measurable post-prandial increase in muscle protein synthesis rates as demonstrated in previous work (Yang et al. 2012b, 2012a).

The modulation of post-prandial plasma leucine availability has also been demonstrated in various studies assessing protein digestion and absorption kinetics and muscle protein synthesis rates after ingestion of different protein amounts (Yang et al. 2012b, Pennings et al. 2012, Yang et al. 2012a), types (Koopman et al. 2009, Pennings et al. 2011) and meals with different macronutrient compositions (Gorissen et al. 2014). By combining the ingestion of intrinsically L- $\left[1-{ }^{13} \mathrm{C}\right]$-phenylalanine-labeled protein with the continuous intravenous L-[ring${ }^{2} \mathrm{H}_{5}$ ]-phenylalanine infusion, some of these studies were able to demonstrate that a greater first pass splanchnic extraction of dietary protein-derived amino acids was likely responsible for the attenuated postprandial rise in plasma amino acid availability (Koopman et al. 2009, Pennings et al. 2011, Gorissen et al. 2014). In the present study, we provided our subjects with intrinsically L-[1- $\left.{ }^{13} \mathrm{C}\right]$-phenylalanine-labeled protein. By collecting blood samples over a $5 \mathrm{~h}$ post-prandial period and measuring both plasma phenylalanine concentrations as well as $\mathrm{L}-\left[1-{ }^{13} \mathrm{C}\right]$-phenylalanine enrichments, we were able to compare the post-prandial rise in dietary protein-derived amino acid availability in the circulation, providing insight into 
dietary protein digestion and amino acid absorption kinetics(van Loon et al. 2009). We observed a modulation in the temporal pattern of dietary protein-derived amino acid availability with protein ingestion in the sitting as opposed to lying position, resulting in a more rapid release of dietary protein-derived amino acids without changing overall plasma availability assessed over the entire $5 \mathrm{~h}$ post-prandial period (Figure 3). These findings indicate that dietary protein-derived amino acid absorption is accelerated when protein is ingested in a seated compared with lying position, resulting in a greater post-prandial rise in plasma essential amino acid and leucine concentrations.

The more rapid release of dietary protein-derived amino acids into the circulation following protein ingested in a seated vs lying down position may be attributed to a delay in gastric emptying rate in the lying position. Therefore, we also assessed gastric emptying rates by measuring the increase in plasma paracetamol concentrations following the combined ingestion of protein with $1.5 \mathrm{~g}$ paracetamol (Glerup et al. 2007, van Can et al. 2014, Holwerda et al. 2016). Peak plasma paracetamol concentrations were substantially higher in the seated vs lying down position $\left(11.6 \pm 0.5\right.$ vs $9.3 \pm 0.6 \mathrm{mgL}^{-1}$, respectively) and were reached 45 min earlier when protein was ingested in the sitting position compared to the lying position (Figure 4). In accordance, AUC analysis of plasma paracetamol concentrations over the first 60 min after protein ingestion revealed a substantially higher gastric emptying rate in the sitting compared with lying position (Figure 4). Furthermore, we observed a significant positive correlation between plasma paracetamol and leucine AUC during the early postprandial period $(\mathrm{t}=0-60 \mathrm{~min} ; r=0.53 ; \mathrm{P}<0.05)$. Altogether, these data show that gastric emptying rates are $23 \%$ slower when protein is ingested in a lying body position, resulting in an attenuated post-prandial rise in circulating plasma amino acid concentrations. Of course, we cannot exclude that other factors, such as changes in splanchnic blood flow, may contribute to the observed differences in post-prandial protein handling following food intake 
in an upright sitting or supine position. These differences in post-prandial amino acid availability are similar to differences observed between slowly vs more rapidly digestible proteins (Koopman et al. 2009, Pennings et al. 2011), implying that body position can strongly modulate post-prandial protein handling in vivo in humans.

The present findings may be of relevance to various settings of disuse atrophy. Disuse atrophy has been partly attributed to a reduced sensitivity of the muscle protein synthetic response to the post-prandial rise in plasma amino acid concentrations, and leucine in particular (Glover et al. 2008, Wall et al. 2016). In the present study, we observed that protein ingestion in a lying body position results in an attenuated rise and overall availability of plasma leucine. Therefore, feeding bedridden patients in a lying down as opposed to a normal upright sitting position may attenuate the post-prandial rise in plasma amino acid concentrations, contributing to a diminished anabolic response to feeding in these patients. Proper upright body position during and after feeding may be a prerequisite to maximize post-prandial muscle protein accretion and, as such, compensate for anabolic resistance.

In conclusion, protein ingestion in an upright sitting as opposed to a lying down position accelerates gastric emptying rate, accelerates dietary protein-derived amino acid absorption, and increases the post-prandial rise in plasma amino acid concentrations. Therefore, an upright body position during and after feeding is recommended when aiming to optimize post-prandial muscle protein accretion. 


\section{DECLARATIONS}

Ethics approval and consent to participate.

This study was approved by the Medical Ethical Committee of the Maastricht University Medical Centre, The Netherlands (METC 14-3-052). All participants provided written informed consent before participation.

\section{Consent for publication}

Not applicable.

Availability of data and material

All data generated or analyzed during this study are included in this published article.

\section{Competing interests}

Authors declare no competing interests

\section{Funding}

This research did not receive any specific grant from funding agencies in the public, commercial, or not-for-profit sectors.

\section{Authors' contributions}

A.M.H., K.L., and L.J.C.L. designed the research; A.M.H. conducted the research; A.M.H., K.L., J.B., W.K.W.H.W. and L.J.C.L. analyzed the data; A.M.H. performed the statistical analysis; and A.M.H. and L.J.C.L. wrote the paper and hold primary responsibility for the final content. All authors read and approved the final manuscript. 


\section{Acknowledgements}

We would like to acknowledge the enthusiastic support of the subjects who volunteered to participate in this experiment. 


\section{REFERENCES}

Bax, M.-L., Aubry, L., Ferreira, C., Daudin, J.-D., Gatellier, P., Rémond, D., et al. 2012. Cooking temperature is a key determinant of in vitro meat protein digestion rate: investigation of underlying mechanisms. J. Agric. Food. Chem. 60(10): 2569-2576. doi:10.1021/jf205280y.

Burd, N.A., Gorissen, S.H., van Vliet, S., Snijders, T., and van Loon, L.J. 2015. Differences in postprandial protein handling after beef compared with milk ingestion during postexercise recovery: a randomized controlled trial. Am. J. Clin. Nutr. 102(4): 828-836. doi:10.3945/ajen.114.103184.

Calbet, J.A.L., and Holst, J.J. 2004. Gastric emptying, gastric secretion and enterogastrone response after administration of milk proteins or their peptide hydrolysates in humans. Eur. J. Nutr. 43(3): 127-139. doi:10.1007/s00394-004-0448-4.

Churchward-Venne, T.A., Burd, N.A., Mitchell, C.J., West, D.W.D., Philp, A., Marcotte, G.R., et al. 2012. Supplementation of a suboptimal protein dose with leucine or essential amino acids: effects on myofibrillar protein synthesis at rest and following resistance exercise in men. J. Physiol. 590(11): 2751-2765. doi:10.1113/jphysiol.2012.228833.

Churchward-Venne, T.A., Snijders, T., Linkens, A.M.A., Hamer, H.M., van Kranenburg, J., and van Loon, L.J.C. 2015. Ingestion of Casein in a Milk Matrix Modulates Dietary Protein Digestion and Absorption Kinetics but Does Not Modulate Postprandial Muscle Protein Synthesis in Older Men. J. Nutr. 145(7): 1438-1445. doi:10.3945/jn.115.213710.

Dangin, M., Boirie, Y., Garcia-Rodenas, C., Gachon, P., Fauquant, J., Callier, P., et al. 2001. The digestion rate of protein is an independent regulating factor of postprandial protein retention. Am. J. Physiol. Endocrinol. Metab. 280(2): E340-8.

Dickinson, J.M., Drummond, M.J., Coben, J.R., Volpi, E., and Rasmussen, B.B. 2013. Aging differentially affects human skeletal muscle amino acid transporter expression when 
essential amino acids are ingested after exercise. Clin. Nutr. 32(2): 273-280. doi:10.1016/j.clnu.2012.07.009.

Dreyer, H.C., and Volpi, E. 2005. Role of protein and amino acids in the pathophysiology and treatment of sarcopenia. J. Am. Coll. Nutr. doi:10.1080/07315724.2005.10719455.

Dreyer, H.C., Drummond, M.J., Pennings, B., Fujita, S., Glynn, E.L., Chinkes, D.L., et al. 2008. Leucine-enriched essential amino acid and carbohydrate ingestion following resistance exercise enhances mTOR signaling and protein synthesis in human muscle. Am. J. Physiol. Endocrinol. Metab. 294(2): E392-400. doi:10.1152/ajpendo.00582.2007.

Fry, C.S., Drummond, M.J., Glynn, E.L., Dickinson, J.M., Gundermann, D.M., Timmerman, K.L., et al. 2011. Aging impairs contraction-induced human skeletal muscle mTORC1 signaling and protein synthesis. Skelet. Muscle, 1(1): 11. doi:10.1186/2044-5040-1-11.

Glerup, H., Bluhme, H., Villadsen, G.E., Rasmussen, K., Ejskjaer, N., and Dahlerup, J.F. 2007. Gastric emptying: a comparison of three methods. Scand. J. Gastroenterol. 42(10): 1182-1186. doi:10.1080/00365520701370922.

Glover, E.I., Phillips, S.M., Oates, B.R., Tang, J.E., Tarnopolsky, M.A., Selby, A., et al. 2008. Immobilization induces anabolic resistance in human myofibrillar protein synthesis with low and high dose amino acid infusion. J. Physiol. 586(24): 6049-6061. doi:10.1113/jphysiol.2008.160333.

Gorissen, S.H.M., Burd, N.A., Hamer, H.M., Gijsen, A.P., Groen, B.B., and van Loon, L.J.C. 2014. Carbohydrate coingestion delays dietary protein digestion and absorption but does not modulate postprandial muscle protein accretion. J. Clin. Endocrinol. Metab. 99(6): 2250-2258. doi:10.1210/jc.2013-3970.

Holwerda, A.M., Lenaerts, K., Bierau, J., and van Loon, L.J.C. 2016. Body Position Modulates Gastric Emptying and Affects the Post-Prandial Rise in Plasma Amino Acid Concentrations Following Protein Ingestion in Humans. Nutrients, 8(4). 
doi:10.3390/nu8040221.

Horowitz, M., Flint, A., Jones, K.L., Hindsberger, C., Rasmussen, M.F., Kapitza, C., et al. 2012. Effect of the once-daily human GLP-1 analogue liraglutide on appetite, energy intake, energy expenditure and gastric emptying in type 2 diabetes. Diabetes Res. Clin. Pract. 97(2): 258-266. doi:10.1016/j.diabres.2012.02.016.

Koopman, R., Crombach, N., Gijsen, A.P., Walrand, S., Fauquant, J., Kies, A.K., et al. 2009. Ingestion of a protein hydrolysate is accompanied by an accelerated in vivo digestion and absorption rate when compared with its intact protein. Am. J. Clin. Nutr. 90(1): 106-115. doi:10.3945/ajen.2009.27474.

Mamerow, M.M., Mettler, J.A., English, K.L., Casperson, S.L., Arentson-Lantz, E., Sheffield-Moore, et al. 2014. Dietary protein distribution positively influences 24-h muscle protein synthesis in healthy adults. J. Nutr. 144(6): 876-880. doi:10.3945/jn.113.185280.

Panahi, S., Khoury, El, D., Kubant, R., Akhavan, T., Luhovyy, B.L., Goff, H.D., et al. 2014. Mechanism of action of whole milk and its components on glycemic control in healthy young men. J. Nutr. Biochem. 25(11): 1124-1131. doi:10.1016/j.jnutbio.2014.07.002.

Pennings, B., Boirie, Y., Senden, J.M.G., Gijsen, A.P., Kuipers, H., and van Loon, L.J.C. 2011. Whey protein stimulates postprandial muscle protein accretion more effectively than do casein and casein hydrolysate in older men. Am. J. Clin. Nutr. 93(5): 997-1005. doi:10.3945/ajen.110.008102.

Pennings, B., Groen, B., de Lange, A., Gijsen, A.P., Zorenc, A.H., Senden, J.M.G., et al. 2012. Amino acid absorption and subsequent muscle protein accretion following graded intakes of whey protein in elderly men. Am. J. Physiol. Endocrinol. Metab. 302(8): E992-9. doi:10.1152/ajpendo.00517.2011.

Pennings, B., Groen, B.B.L., van Dijk, J.-W., de Lange, A., Kiskini, A., Kuklinski, M., et al. 
2013. Minced beef is more rapidly digested and absorbed than beef steak, resulting in greater postprandial protein retention in older men. Am. J. Clin. Nutr. 98(1): 121-128. doi:10.3945/ajen.112.051201.

Rasmussen, B.B., Fujita, S., Wolfe, R.R., Mittendorfer, B., Roy, M., Rowe, V.L., et al. 2006. Insulin resistance of muscle protein metabolism in aging. FASEB J. 20(6): 768-769. doi:10.1096/fj.05-4607fje.

Soop, M., Nehra, V., Henderson, G.C., Boirie, Y., Ford, G.C., and Nair, K.S. 2012. Coingestion of whey protein and casein in a mixed meal: demonstration of a more sustained anabolic effect of casein. Am. J. Physiol. Endocrinol. Metab. 303(1): E152-62. doi:10.1152/ajpendo.00106.2012.

van Can, J., Sloth, B., Jensen, C.B., Flint, A., Blaak, E.E., and Saris, W.H.M. 2014. Effects of the once-daily GLP-1 analog liraglutide on gastric emptying, glycemic parameters, appetite and energy metabolism in obese, non-diabetic adults. Int. J. Obes. 38(6): 784793. doi:10.1038/ijo.2013.162.

van Loon, L.J.C., Boirie, Y., Gijsen, A.P., Fauquant, J., de Roos, A.L., Kies, A.K., et al. 2009. The production of intrinsically labeled milk protein provides a functional tool for human nutrition research. J. Dairy Sci. 92(10): 4812-4822. doi:10.3168/jds.2009-2317.

Wall, B.T., Dirks, M.L., Snijders, T., van Dijk, J.-W., Fritsch, M., Verdijk, L.B., et al. 2016. Short-term muscle disuse lowers myofibrillar protein synthesis rates and induces anabolic resistance to protein ingestion. Am. J. Physiol. Endocrinol. Metab. 310(2): E137-47. doi:10.1152/ajpendo.00227.2015.

Wall, B.T., Hamer, H.M., de Lange, A., Kiskini, A., Groen, B.B.L., Senden, J.M.G., et al. 2013. Leucine co-ingestion improves post-prandial muscle protein accretion in elderly men. Clin. Nutr. 32(3): 412-419. doi:10.1016/j.clnu.2012.09.002.

Waterval, W.A.H., Scheijen, J.L.J.M., Ortmans-Ploemen, M.M.J.C., Habets-van der Poel, 
C.D., and Bierau, J. 2009. Quantitative UPLC-MS/MS analysis of underivatised amino acids in body fluids is a reliable tool for the diagnosis and follow-up of patients with inborn errors of metabolism. Clin. Chim. Acta, 407(1-2): 36-42. doi:10.1016/j.cca.2009.06.023.

Yang, Y., Breen, L., Burd, N.A., Hector, A.J., Churchward-Venne, T.A., Josse, A.R., et al. 2012a. Resistance exercise enhances myofibrillar protein synthesis with graded intakes of whey protein in older men. Br. J. Nutr. 108(10): 1780-1788. doi:10.1017/S0007114511007422.

Yang, Y., Churchward-Venne, T.A., Burd, N.A., Breen, L., Tarnopolsky, M.A., and Phillips, S.M. 2012b. Myofibrillar protein synthesis following ingestion of soy protein isolate at rest and after resistance exercise in elderly men. Nutr. Metab. 9(1): 57. doi:10.1186/1743-7075-9-57. 


\section{FIGURE LEGENDS}

Figure 1 Mean (+SEM) plasma glucose $\left(\mathrm{mmol} \cdot \mathrm{L}^{-1} ; A\right)$ and insulin $\left(\mathrm{mU} \cdot \mathrm{L}^{-1} ; \mathrm{B}\right)$ concentrations after protein ingestion while seated (Upright; $n=8$ ) and while lying in a supine body position (Lying down; $n=8$ ). The data were analyzed with a two-way repeated-measures (treatment $\times$ time) ANOVA. Glucose: time effect: $\mathrm{P}<0.05$; time $\times$ treatment interaction: $\mathrm{P}<0.01$. Insulin: time effect: $\mathrm{P}<0.01$; time $\times$ treatment interaction: $\mathrm{P}<0.05$.

Figure 2 Mean (+SEM) plasma leucine (A), essential (EAAs; B) and non-essential (NEAAs; C) amino acid concentrations $\left(\mu \mathrm{mol} \cdot \mathrm{L}^{-1}\right)$ after protein ingestion in a seated (Upright; $n=8$ ) and while lying in a supine boy position (Lying down; $n=8$ ). The data were analyzed with a two-way repeated-measures (treatment $\times$ time) ANOVA. Leucine: time effect: $\mathrm{P}<0.01$; time $\times$ treatment interaction: $\mathrm{P}<0.05$. EAAs: time effect: $\mathrm{P}<0.01$; time $\times$ treatment interaction: $\mathrm{P}<0.05$. NEAAs: time effect: $\mathrm{P}<0.01$; time $\times$ treatment interaction: $\mathrm{P}>0.05$. Area under the curve over 300 min (arbitrary units, AU) inset and analyzed with a Student's paired t-test. *Significant differences $(\mathrm{P}<0.05)$ between treatments within each time point. \#Trend for a difference between treatments $(\mathrm{P}<0.10)$.

Figure 3 Mean (+SEM) plasma L- $\left[1-{ }^{13} \mathrm{C}\right]$-phenylalanine enrichment (MPE) after protein ingestion in a seated (Upright; $n=8$ ) and while lying in a supine body position (Lying down; $n=8$ ). The data were analyzed with a two-way repeated-measures (treatment $\times$ time) ANOVA: Time effect: $\mathrm{P}<0.01$; time $\times$ treatment interaction: $\mathrm{P}<0.01$. Area under the curve over 300 min (arbitrary units, AU) inset and analyzed with a Student's paired t-test.

Figure 4 Mean (+SEM) plasma paracetamol concentrations $\left(\mathrm{mg} \cdot \mathrm{L}^{-1}\right)$ after protein ingestion 
in a seated (Upright; $n=8$ ) and while lying in a supine body position (Lying down; $n=8$ ). The data were analyzed with a two-way repeated-measures (treatment $\times$ time) ANOVA: Time effect: $\mathrm{P}<0.01$; time $\times$ treatment interaction: $\mathrm{P}<0.01$. Area under the curve over $300 \mathrm{~min}$ (arbitrary units, AU) inset and analyzed with a Student's paired t-test. *Significant differences $(\mathrm{P}<0.05)$ between treatments within each time point. 
Paç 25 of 28pplied Physiology, Nutrition, and Metabolism

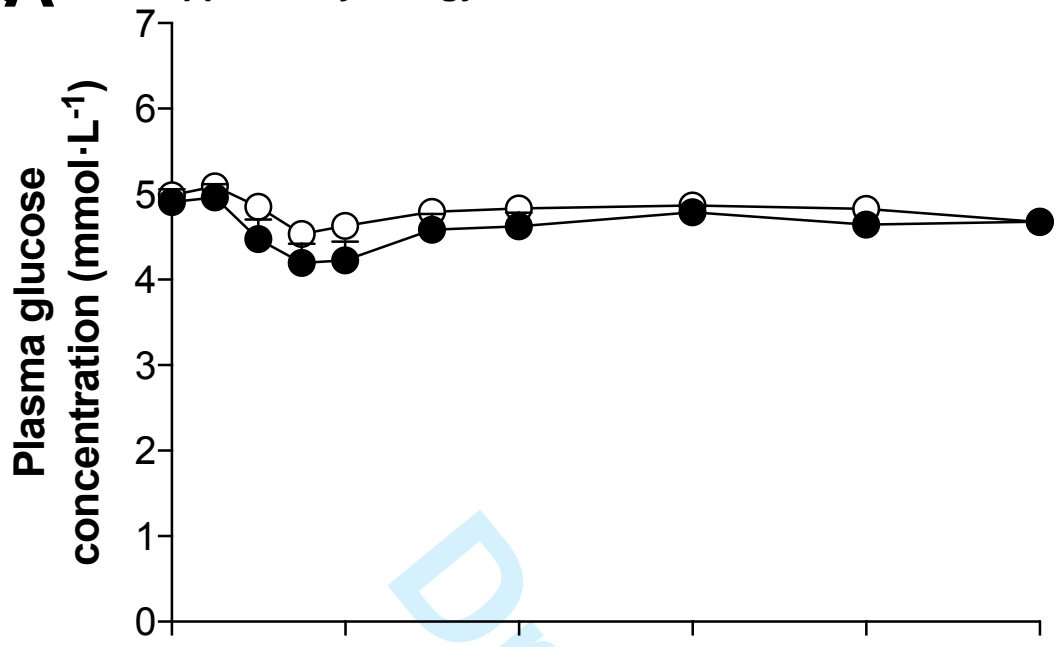

B

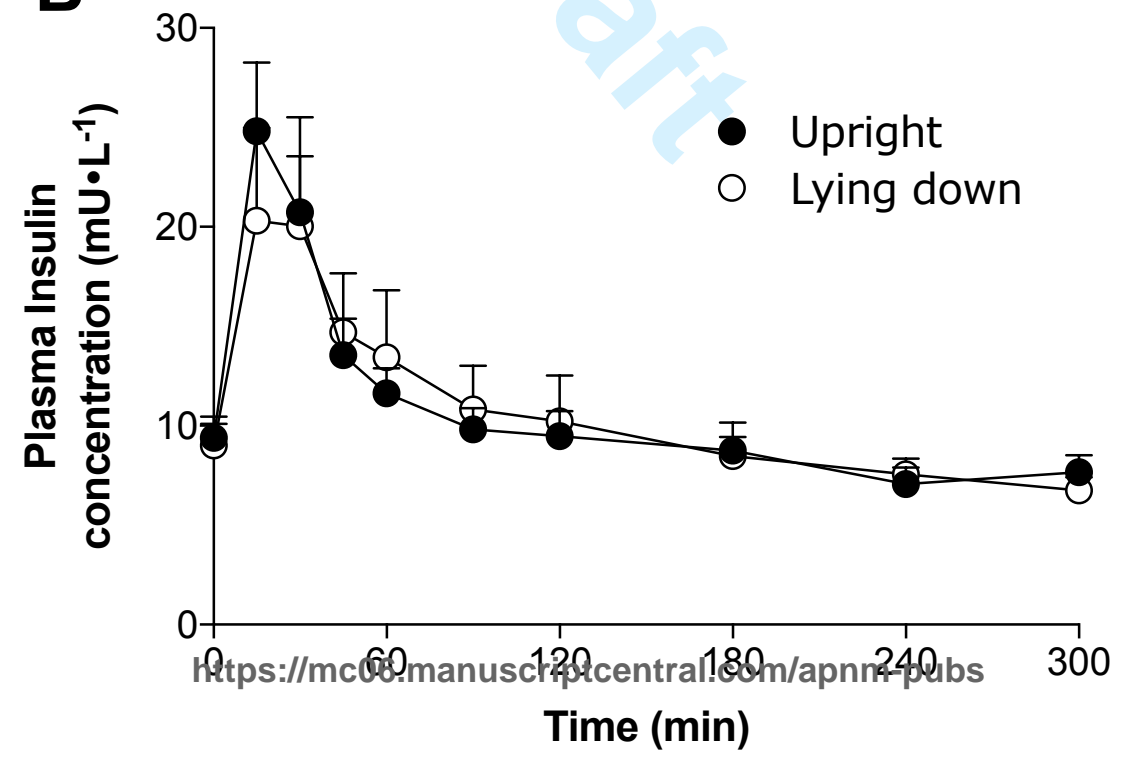




\section{Applied Physiology, Nutrition, anoPatom}

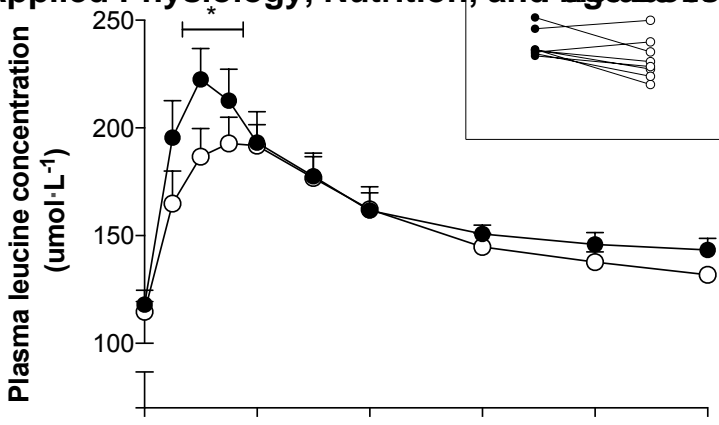

B

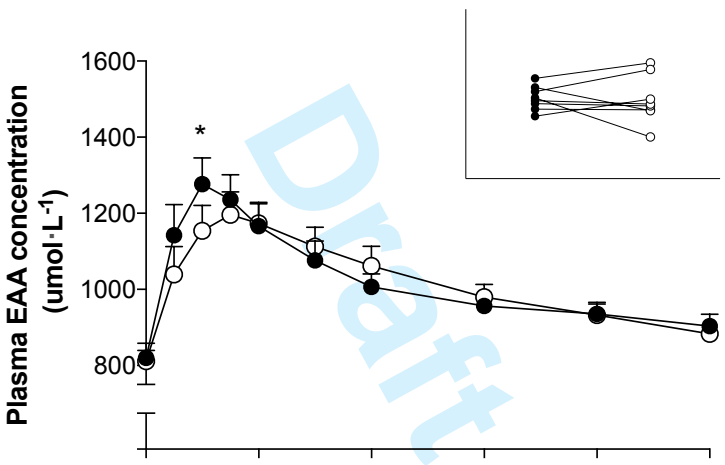

C

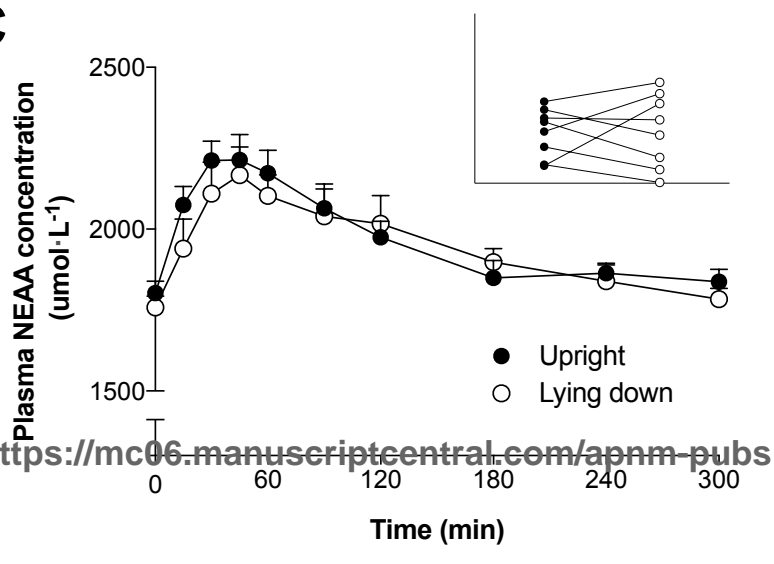


Page 2720.529pplied Physiology, Nutrition, and Metabolism

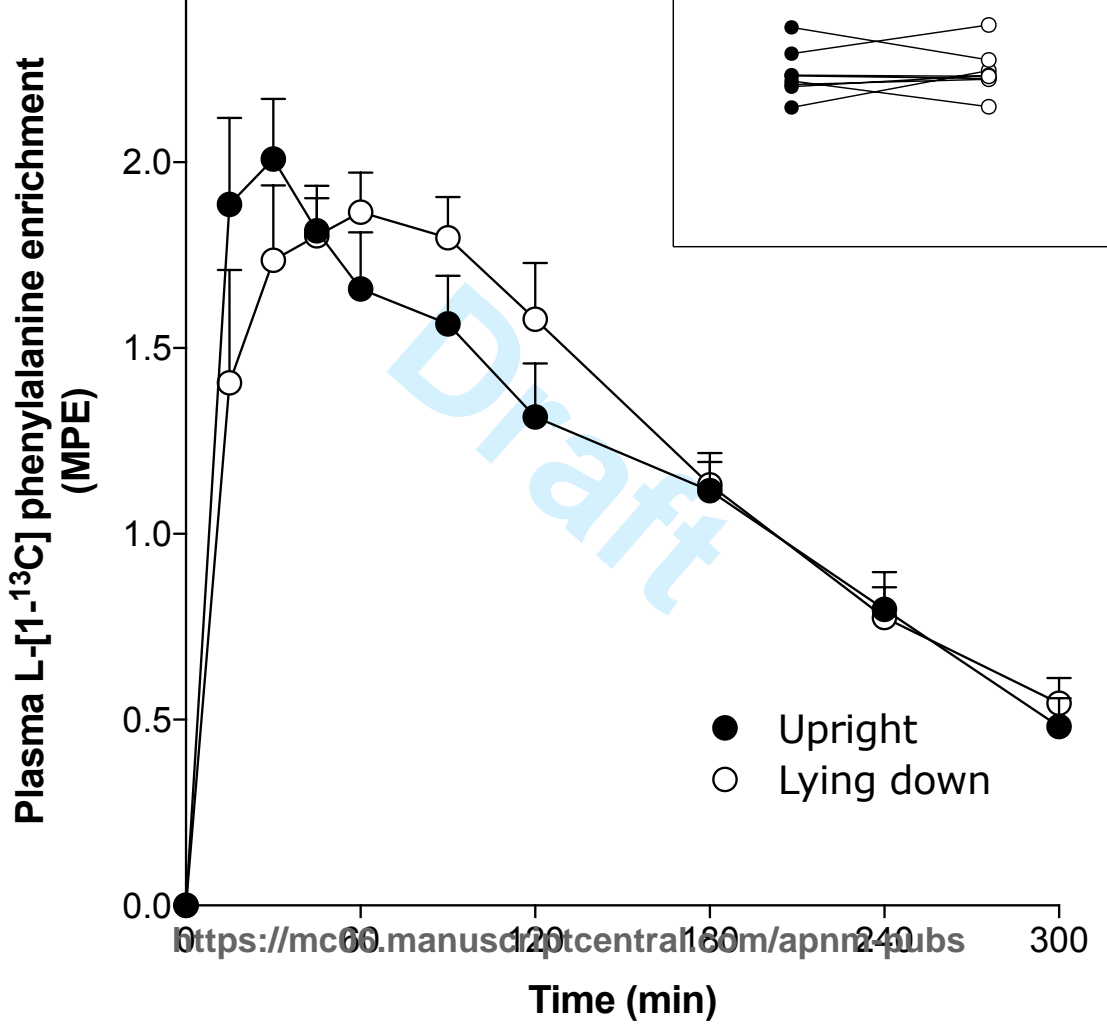




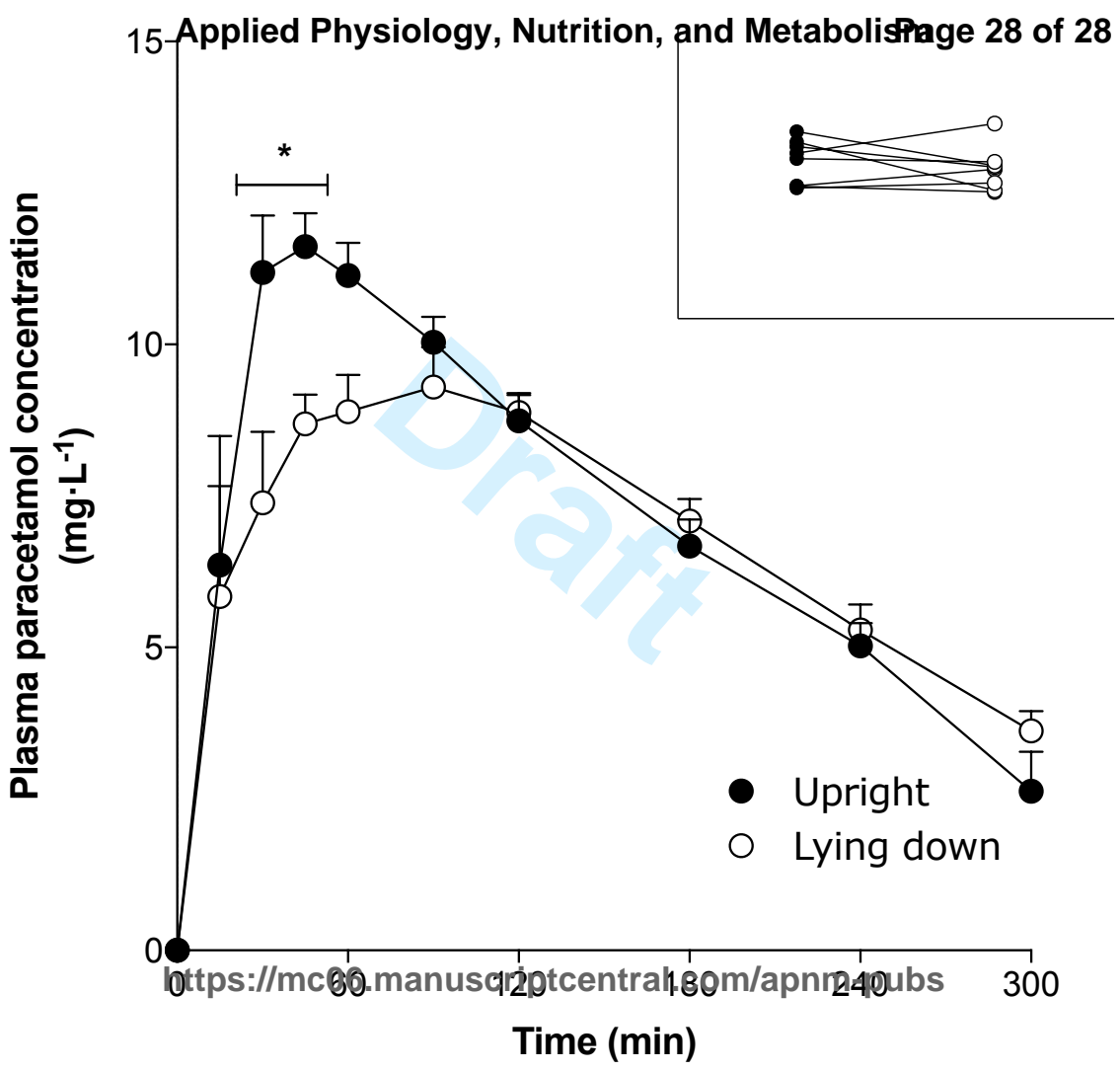

